\title{
Tourism Policy and Organization:Case Study of Penang National Park
}

\author{
Nuradilah Abas, Ng Chun How, Yap Sui Chai, Khor Ying Jia, Nur Munirah Marzuki, Nor Azwa Syahida Mat Suhaimi, Jason \\ Chan Qing Wang, Norhanani Ahmad,Nurul Sahkinah Sahrum, Hafizah Hairi,Nurul Iman Darus, Sheilawanis Abdul Karim \\ School of Housing Building and Planning \\ Universiti Sains Malaysia \\ Pulau Pinang, Malaysia \\ nuradilah.abas80@gmail.com
}

\begin{abstract}
The Penang National Park (PNP), the smallest national park in the world, was formerly known as Pantai Acheh Forest Reserve. Penang National Park processes some unique characteristics. Among them, its diversity of ecological habitats, the rich fauna and the number of unique flora found. The Penang National Park is one of the few remaining areas on Penang Island which still comprises natural rainforest and small mammals. This park has a number of habitats like dipterocarp forest, riparian, mangroves, coastal area and Meromictic Lake. It is one of the few natural heritages in Northern Peninsular Malaysia with unique feature such as Meromictic Lake which natural process of inundating and drawing out water from this lake happen intermittently and its bottom layer is made up of warm salt water from the sea, and the upper layer comprising cool and fresh water from river and rain. Declared as national park in 2003, these features could prove to be potentials and
\end{abstract} opportunities for ecotourism. The study focuses to five main places in Penang National Park which is the main office to national park, Centre for Marine and Coastal Studies (CEMACS, USM), Teluk Duyung known as Monkey Beach, Teluk Kampi and Pantai Kerachut. Pantai Keracut is known as place for turtle sanctuary where from September to February the beach is full with Olive-Ridley Turtle (Lepidochelys olivacea), while from April to August, visitors can see the Green Turtle (Chelonia mydas) nesting ground. The SWOT analysis of policy and organization in PNP have been taken by using Naturalism Qualitative approach. SWOT analysis has shown that the Penang National Park are embodied with the Malaysia National Park Policy and 1980 Act. Based on the SWOT analysis the accessibility feature and the uniqueness of environment landscape of PNP are the strength whereas the inefficient of enforcement of rules and regulation policy management were found to be the weakness. Creating an environmental awareness through education program and collaboration with the NGOs services would help in promoting the PNP as an ecotourism destination were found to be the main opportunities. The loss of flora and fauna and the environment issue were found to be the main threat. Through the finding, TOWS analysis technique was deployed to identify the strategic policy and regulation options. It was conducted in manner that internal strength and external opportunities were maximized while the internal weaknesses and external threats on the PNP were minimized. Several strategic policy for PNP in ecotourism context have been identified which are enhance the enforcement of PNP rules and regulation planning for the visitor and set a sustainable guidelines for future development in national parks. In addition, strategic option has been identified to counter against the external threats and internal weakness such as insufficient of enforcement policy and encroachment and poachers of flora and fauna. Understanding this information will help park managers to create an efficient park management, and thus will make contribution to the long term sustainable development of ecotourism areas especially national parks. This information, not only important for management and planning purposes but also implementation of policy and regulation process.

Keywords- Penang, tourism policy, ecotourism, national park, wildlife, turtle sanctuary, MeromicticLake

\section{INTRODUCTION}

\section{A.History \& Origin of Penang National Park}

The Penang National Park (Taman Negara Pulau Pinang) is located on the north-western tip of the island at Teluk Bahang. It is the smallest national park in the country with a size of 2,562 hectares. Before the area was gazetted in 2003 as national park, the locals knew it as Pantai Acheh Forest Reserve.

Figure 1.1: Location of Penang National Park

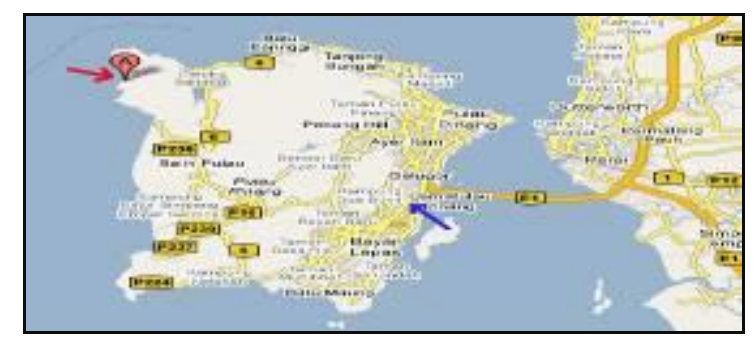

Figure 1.2: Area covered in Penang National Park

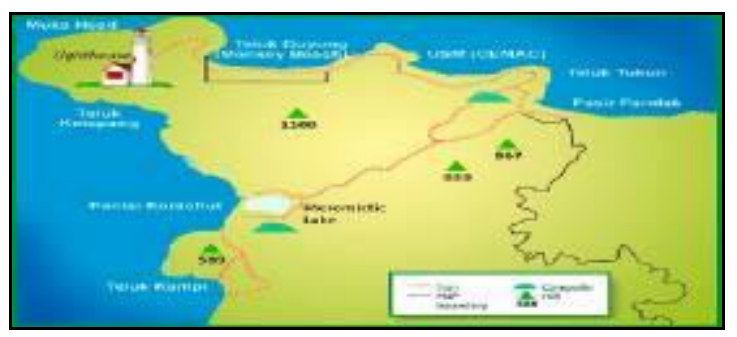

Penang National Park was formed under National Park Act 1980, Act No. 226. The reserve was turned into a national park with the effort from Penang State Government, Federal Government, non-government organizations and local community about the concern of the importance to protect 
various biological areas of forests in metropolitan areas. This National Parks Act 1980 is a Malaysian federal law that governs the creation and the maintenance national parks in Malaysia. It was created in 1980 during the controversy surrounding the protection of Endau Rompin forest complex. The act provides for the states to establish national parks to be administered by Department of Wildlife and National Parks under the federal government and it is controlled by 'Majlis Penasihat Taman Negara'.

Penang National Park it is home to 46 species of birds such as the Stork-billed Kingfishers, White-breasted Waterhens and Great Egrets. A 2000 expedition led by the Malaysian Nature Society recorded 417 flora and 143 fauna species. The park with its rainforest and beaches is a great place to go jungle trekking, camping, fishing, wildlife and bird spotting, or just relax on one of its beautiful beaches.

There are two main hiking tracks through the forest and unless you are extremely fit you will need two separate day trips to do both. The tracks through the jungle are often steep, wet and tricky with lots of roots, tree trunks and sometimes rocks to climb over. One route takes you along the coastline to Monkey Beach (Teluk Duyung), then on a steep climb up to an elevation of $227 \mathrm{~m}$ to Muka Head Lighthouse. The other takes you over the headland to Kerachut Beach (Pantai Kerachut) where you will find a rare meromictic lake (a lake of layers where sea and fresh water do not mix) and the Penang Turtle Sanctuary. Green Sea Turtles come up on the beaches here to lay their eggs from April and August and Olive Ridley Turtles, between September and February. For those who not prefer tracking in the jungle, they may rent a boat from the jetty to Kerachut Beach, Monkey Beach or Muka Head Lighthouse. Prices for hiring the whole boat (for up to 10 people) are currently RM50 for Monkey Beach and up to RM100 to take you around the peninsular to the turtle sanctuary.

Figure 1.3: Signage of Penang National Park

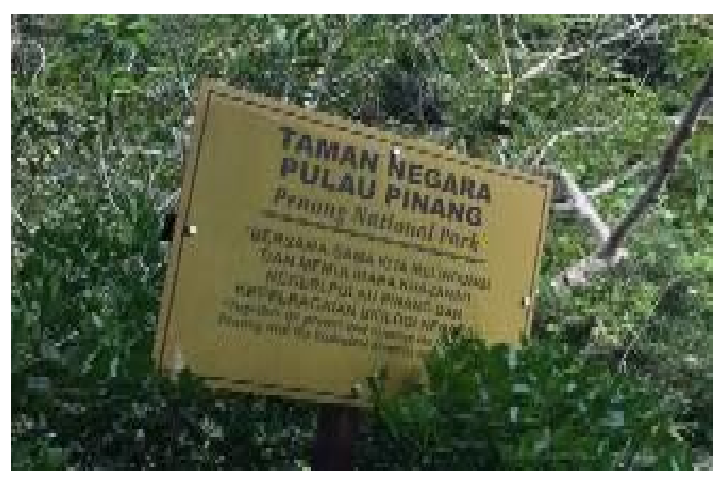

Figure 1.4: Signage at the entrance of Sungai Tukun Forest Reserve

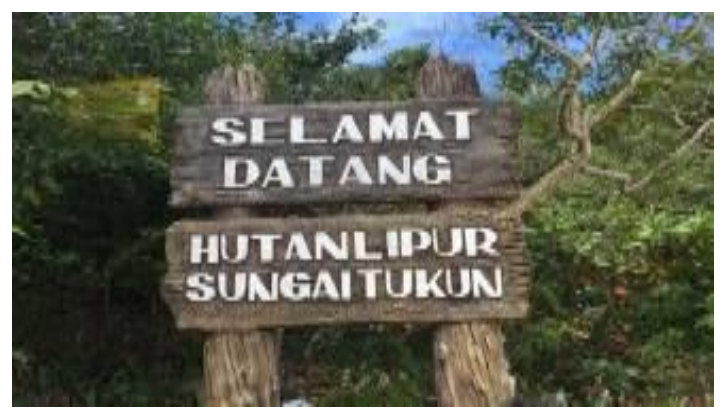

\section{B.Facilities \& Services}

Facilities and services that are developing in protected areas must have balance with the environment by knowing the conservation goals, necessity of facilities usage, and importance of the infrastructures (Hearne \& Salinas, 2002). Maintaining of the facilities at Penang National Park is done by using funding from the government and fees for activities that is being charged (Hong \& Chan, 2010). Beach attractions at Penang National Park are Teluk Bahang, Pantai Kerachut, Pantai Mas, and Monkey Beach (Samdin \& Aziz, 2011). No major development and high risk activities can be carried out near the forest of PNP as the area is environmentally and ecologically sensitive (Chan, 2003)

According to National Park Act 1980, national park officials should set a time frame in which the public can visit the national park. Upon arrival, there will be an information counter located at the entrance of the national park which is open daily from 7:30 a.m. to 6 p.m. Visitors need to register themselves by leaving their name, gender, age, and identification number for safety reason. Visitors are also required to note down their plans and length of stay. A copy of a map of the trekking trails is given after registering.

There are also national park act states 1980, issuance of permits required for entering or camping in the national park because to regulate conduct, obligations and duties of the end of the visit or walk, exploring or camping in a national park and visitors' safety are taken in the event of an accident or missing it will available search operation to be carried out by the national park. There are two lanes, one for Malaysian visitors and another special lane for foreigners. The park is free except for the canopy walk activity where the adult fee is RM5.00 and for children it is RM3.00. Ticket must be purchased at the window before entering the park or visitors will be denied to pass through. During visitation, the Canopy Walk is temporary closed for maintenance. At this information office, there are toilets and showers available for visitors. Opposite of the office, there are small shops for visitors convenience. 
Figure 1.5: The Penang National Park

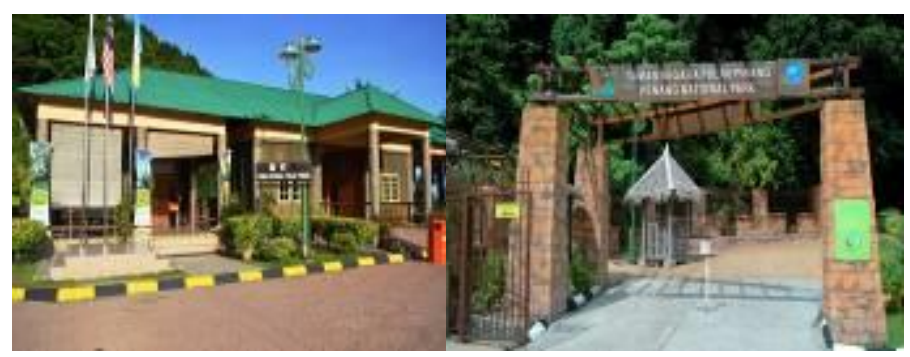

Figure 1.7: The Canopy Walk (under maintenance)

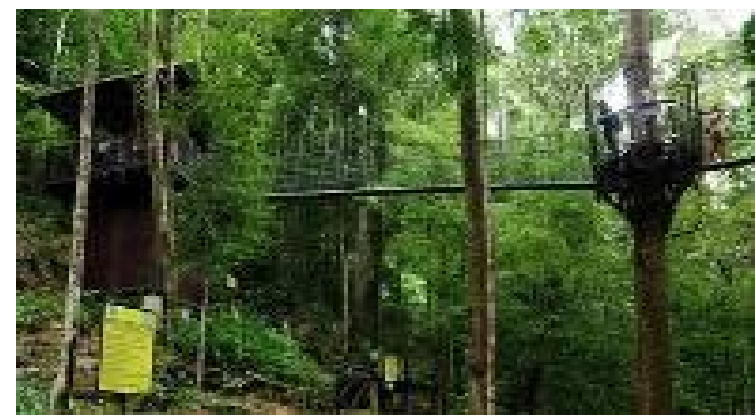

PNP only receives daily visitors. Camping is allowed but need to seek request from the management. Not all places are allowed to build a campsite as this is to minimize human impacts on the park. PNP offers programs for camping at the park through organization such as schools, colleges or higher learning institutions, which offers activities such as conservation education programs. There is no accommodation at the PNP but visitors are welcomed to stay at the nearest hotels at Teluk Bahang and the areas are full of facilities and amenities for visitors.

Visitors have two options to explore the PNP, by walking through the trails provided or by taking the boats. Several boat operators are located near the park entrance. Visitors can arrange and book boat to go to various locations. The price is charged by per boat and the destinations. It costs RM 100 for a boat that can fit 10 persons.

Figure 1.8: Stalls selling boat packages

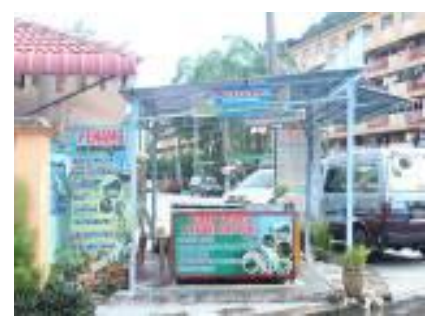

Figure 1.9:Piers at the Penang National Park

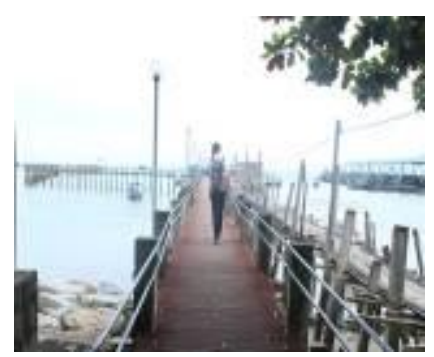

Figure 1.6: Small Shops near the entrance

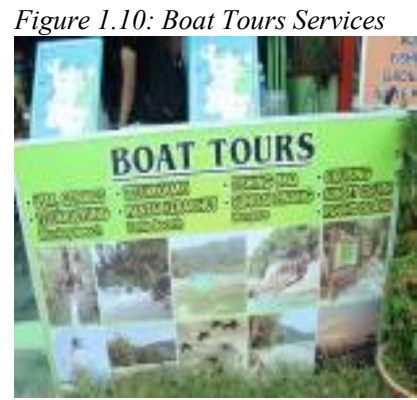

Figure 1.11:Tourist at the boat packages stall

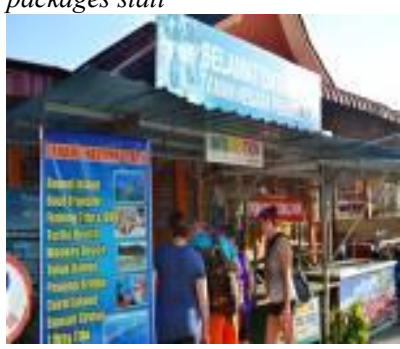

Figure 1.12: Boats for carring visitors

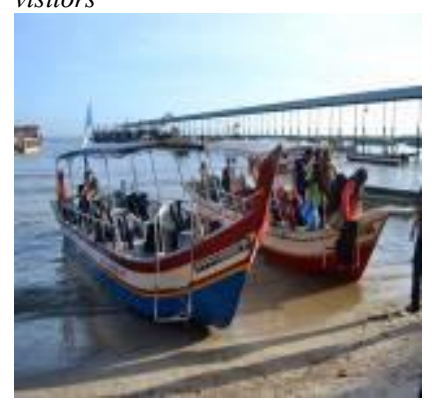

Figure 1.13: Benches available near food stalls

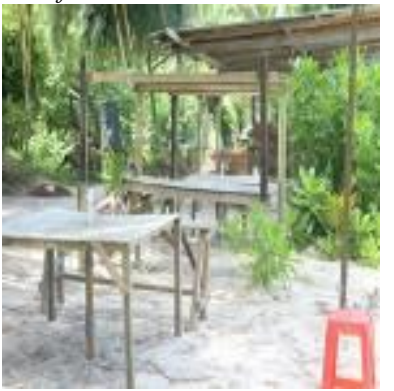

The richness in biodiversity and wildlife of Penang National Park offer variety of opportunities for research, education, ecotourism, and activities for visitors. The offered activities in Penang National Park are compatible with the National Park guidelines which according to Guidelines No. 4 (National Park, reserved forest and other forest) and Guidelines No. 9 (Beach Sites) activity that allow in forest and beach is bird watching, swimming, photography, wildlife observation, nature education, climbing, camping, canoeing, rafting and sunbathing.

Visitors can enjoy trekking through the trails provided, swimming at the beach, doing wildlife observations or just enjoying the nice panoramic view. Throughout the Park, there are rest stops with picnic tables provided. Visitors are allowed to have picnic at the beach area. Visitors who love to do bird-watching can do so at Kuala Sungai Pinang as 
the mangrove area is an extraordinary birding area. Little Heron, Haliaeetus Leucogaster (Helang Siput), Haliastur Indus (Lang Merah), and some other small colorful birds, such as sunbirds (Kelicap) and sandpipers (Kedidi) are examples of birds that can be found at this site (Kaffoshi et al, 2009).

Hiking trails provided by the PNP are wellmaintained. There are three trails to choose. A canopy walkway is a shortcut for two main trails. The walkway is a great are for bird watching and has a nice view of the river below. At Monkey Beach, there are many stalls that sell food and drinks available there. Visitors are also offered with vast activities such as horse riding, banana boating, kayaking and parasailing despite some of the activities are illegal by law. Based on Guidelines for Beach Site (No.9), beaches are a common asset to which public access cannot by law be restricted and beaches act as nesting grounds for various marine and estuarine turtles and for some species of coastal birds. So activities using motorized vehicles are illegal by law such as ATV riding, jet skiing, parasailing and banana boating at Monkey Beach because no motorized vehicles should be allowed on the beaches because taking care about safety standards of swimming area. Stalls at the Monkey Beach also not build according of guidelines for Beach Sites because the stall should setback of 50 meters away from high water mark because it can be disrupt turtle nesting behavior and problem of littering.

At Pantai Kerachut there is a forest rangers office. At one time, there will be two Ranger Officers on duty. Sometimes these rangers get accompanied by the Fishing Rangers. According of National Park Act 1980, officers must be placed in the national park for the purpose of enforcing the law enshrined in the act. This is where they can manage Tsunami warning as the system is planned near the beach area. Any drastic of changes of the tides can give early signs of natural disaster such as earthquake or tsunami, Prayers room is also located here at Pantai Kerachut. It is not advisable to swim in the sea at this area as the tide is high compare to other beaches and the beach levels are uneven. Overnight campers are limited for up to 80 and up to 30 for Sungai Tukun campsite as there is limitied water supplies and rain possibility (Source: Officer).
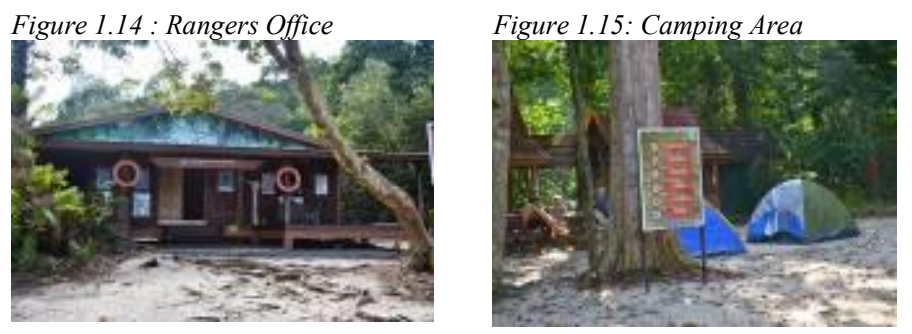

Figure 1.16 : Warning Sign at Kerachut Beach

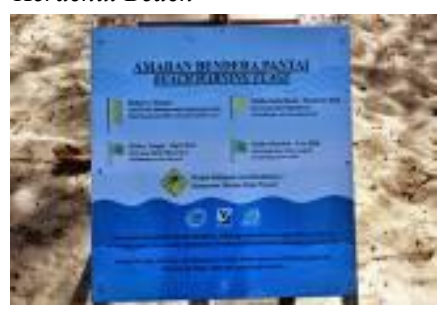

Figure 1.17 : Public toilets

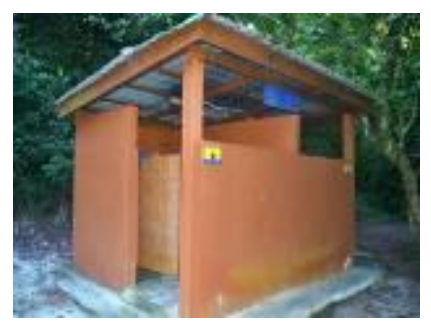

The Penang Turtle Sanctuary that is located at Kerachut Beach provides educational activities for visitors. At certain day, visitors are welcomed to join when they are going to release the young turtles back into their wild nature. From September to February the beach is full with Olive-Ridley Turtle (Lepidochelys olivacea), while from April to August, visitors can see the Green Turtle (Chelonia mydas) nesting ground (Chan, 2009). Nearby of the Turtle Sanctuary, there is an open hall for visitors to use as prayer or communal activities.

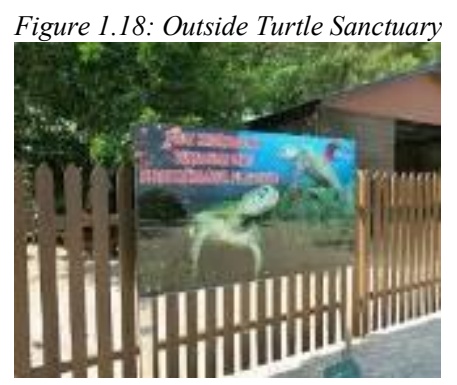

Figure 1.19:Baby turtles that just hatched

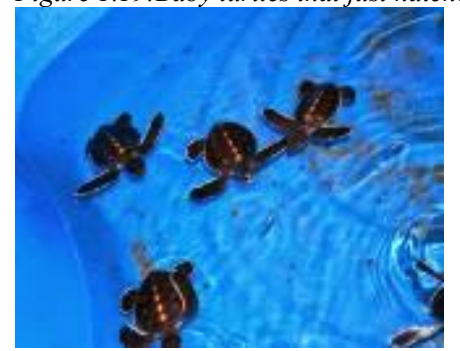

Figure 1.20:Open hall for activities

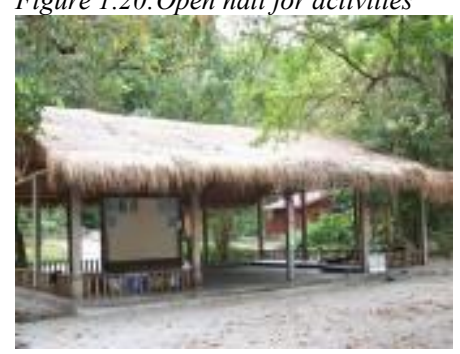

\section{C.ELEMENT OF PENANG NATIONAL PARK}

Penang National Park processes some unique characteristics. Among them, its diversity of ecological habitats, the rich fauna and the number of unique flora found. The Penang National Park is one of the few remaining areas on Penang 
Island which still comprises natural rainforest and small mammals. This park has a number of habitats like dipterocarp forest, riparian, mangroves, coastal area and Meromictic Lake. Each of these elements have own unique features.

Figure 1.21: The forest type in Malaysia (Malaysian National Conservation Strategy, 1993).

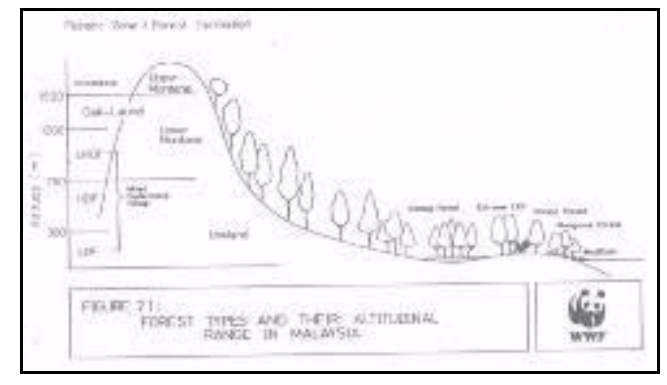

\section{Dipterocarp Forest}

Penang National Park have the dipterocarp forests one of the natural attraction. Based on National Forestry Policy 1978 (revised 1993) aims to conserve and manage the forest through sustainable management and maintain its important roles on the national economy and preservation of environmental stability (Gillis, 1988). The Dipterocarpaceae are a family of 17 genera and approximately 500 species of mainly tropical lowland rainforest trees (Cannon \& Leighton, 2004). The family name, from the type genus dipterocarpus. Stands of Seraya (Shorea curtisii) trees (Herningtyas et al., 2012), common feature of coastal dipterocarp forest, can be easily seen on steep slopes around Muka Head Penang National Park.

The lowland dipterocarp forest on slopes is above the boundary between nearly level coastal plains and hills, from above about 100 metres upwards to 300 metres altitude, the lowland dipterocarp forest is similar to the previous forest is similar to the previous category but poorer in species diversity of some plant and animal groups (Vincent et al., 1993).

There are over 1000 species of plants recorded in Penang National Park which is Chengal, Meranti Seraya, Jelutong, Gaharu, Tongkat Ali dan Bintangor. But, in the forest of Penang National Park is dominated by Meranti Seraya, which typically grows in hill dipterocarp forest everywhere, but normally at higher elevations (Department of Wildlife and National Parks (DWNP) Peninsular Malaysia (n.d.). The forest here is old secondary forest, interspersed with pockets of primary jungle.

Hill dipterocarp forest occurs between about 300 and 950 metres altitude, lower on coastal hills and higher on the flanks of big hill ranges. It often has a high proportion of big timber trees and open understory with little regeneration. This forest type is particularly important in reducing soil erosion (Vincent et al., 1993).

\section{E. Riparian}

According to section 5 of the National Land Code, the river means any river, stream, creek or other natural water flow, and any branch of the river, rail-delta or artificial diversion of it. The definition of river is given under section 2 of the Water Act 1920, which includes the branches of the river and the rail or any natural water flows and canals which are subject to this act (Wahab \& Yaacob, 2012). Under the Environmental Quality Act 1974 and Water Pollution Control Act of 1979, the government enforced the law to control water pollution. So anyone not authorized to make any pollution in rivers such as virtue of its temperature, chemical or biological content or its effect in discoloring the waters makes or contributes to making such river or part thereof a potential danger to public health, safety or welfare or to animal or vegetable life or health, or affects other beneficial uses of such river (Azmi, Akil, and Mansor, 2008).

Cover 23-hectares of rainforest, Sungai Tukun is a small but charming place to enjoy the treasures of nature. For bird-watchers, the Sungai Tukun area attracts white-bellied eagles, eaglets and kingfishers (Bransbury, 1993), while those who want a panoramic view of Teluk Bahang and Batu Feringgi can climb up to the observation tower. Camping grounds and dormitories are available for those who wish to spend a night out in the forest.

\section{F. Meromictic Lake}

According to the National Parks Act 1980, Act No. 226, the main purpose of the establishment of the Penang National Park is to preserve and protect wildlife, marine life, vegetation and objects of interest from geological, archeology, history and ethnology and other interests of scientific and scenic, and the conservation and utilization to promote education, health, aesthetic and recreational values of the public (Taman Negara Pulau Pinang, (n.d.). As we know in Meromictic Lake there are various forms of aquatic life from freshwater and saltwater, so we need to preserve and protect the lives from the threatened.

Meromictic Lake is the only one of its kind in the western coast of peninsular Malaysia and can only be found at Pantai Kerachut, Penang National Park. The meromictic lake total area is estimated to be approximately 2.77 square $\mathrm{km}$ with a maximum depth at 9 feet (Penang National Park, 2013). In full capacity, the lake can provide water to 2,500 household for one year. As a matter of fact, the lake is only available at 19 places around the world. The lake receives its water supply from 5 river tributaries that flow into it as well as from seasonal inundations of seawater.

This lake where fresh and salt water creatures coexist into different layer and which does not mix with each other. Fresh water is relatively lower in density as compared to the hypersaline sea water. The natural process of inundating and drawing out water from this lake happen intermittently. The bottom layer is made up of warm salt water from the sea, 
and the upper layer comprising cool and fresh water from river and rain (Meromictic Lake Pantai Kerachut (n.d.).

It can be witnesses in the month of April to May and October until November which is the transitional period between monsoons. During these periods, huge waves and strong wind will move sand to from natural dam. Eventually, the lake will be filling with the sea and river water that surround it. Similarly, the huge wave and strong wind can crush down the dam, and draw the water out of the lake. This phenomenon can take place several times within transitional period. During low tides and dry seasons, the lake becomes a field of mudflats.

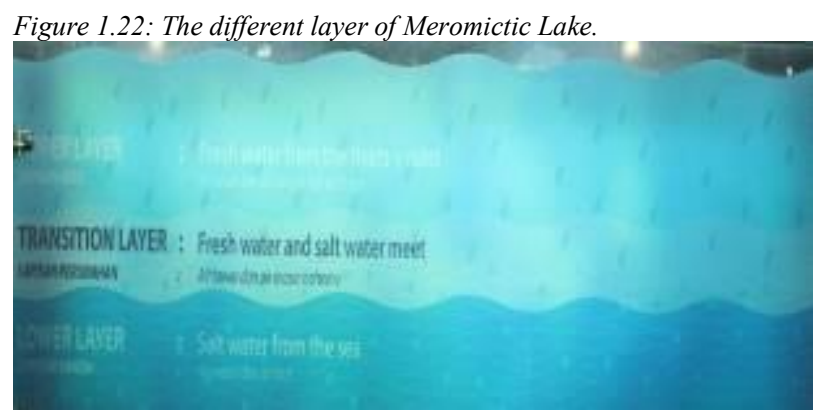

Figure 1.23: The Meromictic lake formation

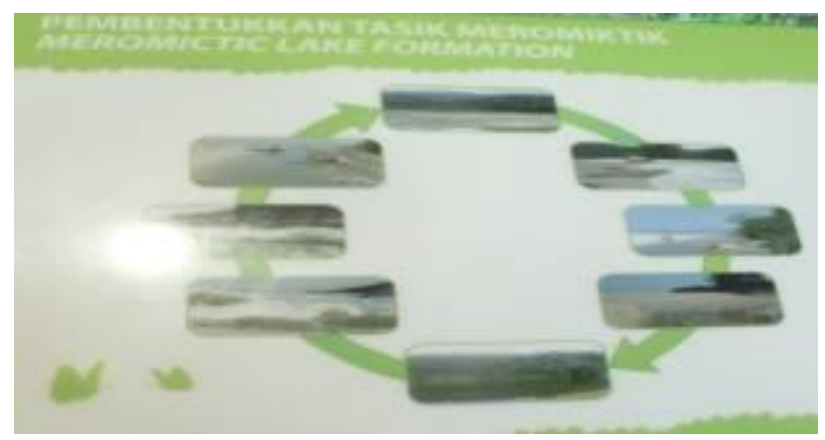

\section{G. Mangrove Forest}

Mangrove forest area in Penang National Park under the National Parks Act 1980 where Penang National Park should preserve and protect wildlife, marine life, plant and objects of interest from geological, archeology, history and ethnology and other interests of scientific and scenic, and the conservation and utilization to promote education, health, aesthetic and recreational values of the public (Taman Negara Pulau Pinang, (n.d.). Penang national park party responsibilities in maintaining and protect the mangrove trees from being cut down and destroyed by people who are not responsible.

Mangrove can be found in over 118 countries and territories in the tropical and subtropical region of the world. Approximately $75 \%$ of the world's mangroves are found in just 15 countries. Asia has the largest amount is about $42 \%$ of the world's mangrove. There are 586.036 hectares of mangrove forest in Malaysia where 57\% in Sabah, 26\% in Sarawak and $17 \%$ in peninsular Malaysia (Jusoff and Taha,
2009). Mangrove forest is located at Pasir Pandak. The area is disturbed with sandy beach and seasonal muddy seabed (Penang National Park, 2013).

Mangroves occur on sheltered, intertidal mud that is saline, often anaerobic, and sometimes acidic. It contains about six major genera of trees, and a very wide range of animal life of all sort. Mangrove trees are very special trees where being able to survive and thrive in salt water and can grow along coasts and river mouths, where no other trees can grow. Mangrove trees have elaborate root systems that help to keep the soil together and that can even cause land to form when new soil from other areas gets stuck between the roots over time. Furthermore, mangrove forests can help protect coastal zones against erosion and extreme weather.

Mangroves have major economic and social importance in supporting and are also a home to water birds and an abundance of sea life, like fish, prawns, crabs and shellfish; coastline protection and built up, forest product and huge another of variety domestic uses (Hutchings \& Saenger, 1987). The sheltered conditions between the roots provide an essential nursery for young sea life, which will eventually grow into a source of seafood and livelihood to millions of people living in coastal areas. In addition to this, mangroves provide wood for building homes and for making charcoal.

\section{H. Shoreline}

There are 5 beaches in Penang National Park. The beaches of Penang National Park are popular amongst tourist as well as locals. Each beach has its own uniqueness, richness of variety of floras and faunas and its potential attraction to tourism activities. There are Pasir Pandak Beach, Teluk Aling Beach, Teluk Duyung (Monkey Beach), Pantai Kerachut and Teluk Kampi (Penang National Park, 2013).

The act of shoreline in Penang National National Park is under the National Parks Act 1980 that is have to preserve and protect the wildlife, aquatic life and plant. So, everybody that come to Penang National Park should comply with the regulation under the act and for those who violate the regulation will be punished. The prohibition that will caused the pollution to the water is under the Environmental Quality Act 1974 must also be followed (Abdul Wahab and Yaacob, 2012). As stated in the Fisheries Act 1985, catching aquatic mammals and turtles in Malaysian waters is prohibited and shall be fined not exceeding one hundred ringgit (Undangundang Malaysia, 2012). This act is to protect the aquatic mammal species and turtles and prevent extinction. 


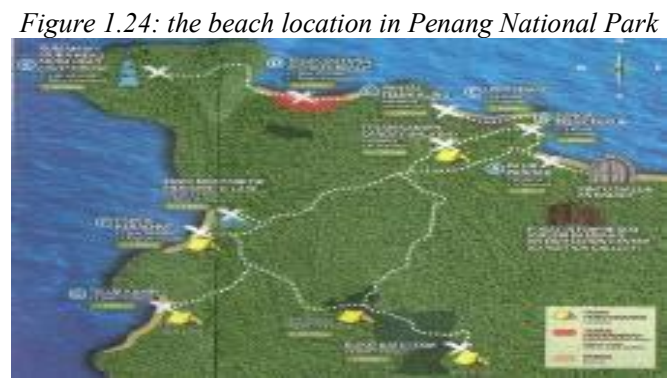

Pasir Pandak Beach is the area where the Bahang Bay is located. The panoramic fishing jetty engulfing the backdrop is a rare sight by itself-built mangrove timber and palm trunks. This scenic beach is bustling with tourist and campers going into the national park. The area is disturbed with sandy beach and muddy seabed.

Teluk Aling Beach is the USM's (Universiti Sains Malaysia) research Centre that being call Centre for Marine \& Coastal Studies (CEMACS). There is a jetty to bring in supply from town. The forest and coastal areas are been used for research on bio-technology. The research station's collection museum has vast collection of flora and fauna exhibits.

Teluk Duyung or known as Monkey Beach is a beautiful bay protected by the Muka Head's cape. It is the most popular beach for tourists. Teluk Duyung is also called Muka Head, named after the Muka Head's peak which stands a majestic lighthouse. Muka Head lighthouse was built in 1883 and being functions as a marker for ships and sailors negotiating the northwestern cape of Penang. It was the second lighthouse built in Penang. According to officer from Penang National Park during the interview session, Monkey Beach is a private land owned by Boon Siew Group.

Pantai Kerachut famous for its seasonal Meromictic Lake, it is a popular picnic and camping site and famous turtle hatchery. Collecting of the turtles' eggs is prohibited in Pantai Kerachut. Pantai Kerachut is the beach that becomes a nesting site for the Green Sea Turtle (Chelonia mydas), the Olive Ridley turtle (Lepidochelys Olivacea), and the Hawksbill Turtles (Eretmochelys Imbricate).

It is believed that the Green Turtle only migrate here for nesting as extensive algae are not known and found around Penang Island. It is one of the largest sea turtle and the Penang National Park will ensure the continuity of the turtle's visit.

Teluk Kampi has the longest beach in the park. Tell signs of trenches were found along the northern coast indicating a defense post for the Japanese Army. Historically this could be the best landing place for seafarer. There are many artifacts and past history to be found if one is to venture further.
Figure 1.25: Turtle conservation \& Information Centre

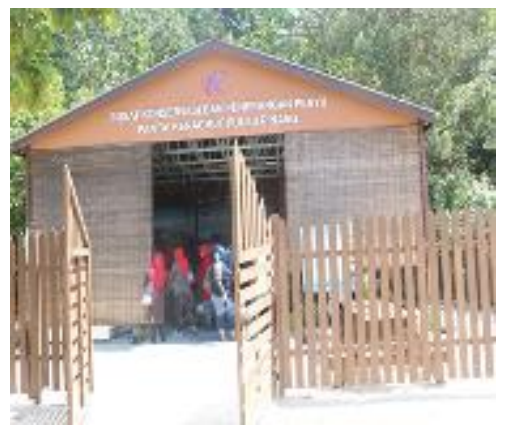

II.OBJECTIVE

As one of the tourist destinations in Penang's Island, Penang National Park is chosen as the study area to explore and analyze the problem and issues relating to policies and organizations involvement. This paper specifically identifies the strengths, weaknesses, opportunities and threats (SWOT) of the Penang National Park relate in context of policy and regulation. The study of SWOT analysis is important in order to create sustainable eco-tourism in Penang. The policy and regulation facets inevitably play a main role in manage national parks, by insight the main policy and regulation in the PNP could alienate the main destruction on the ecosystem. Moreover, the main objective towards the establishment of National Parks is to preserve and protect of wild life, plant life and objects of geological, archaeological, historical, and ethnological and other scientific, scenic interest and through their conservation and utilization to promote the education, health, aesthetic value and recreation of people under National Parks Act 1980. Hence, this analysis is catalyst a strategic to create a better sustainable development in PNP. TOWS analysis is subsequently deployed to identify the best options for strategic policy and regulation in management of PNP.

\section{III.METHODOLOGY}

\section{A.SWOT Analysis}

SWOT analysis is an examination towards an organization's internal strengths and weaknesses, it's consist of opportunities for growth and improvement and threats for external environment presents to its survival. Implementing SWOT analysis involves significant symbolic processing, complexity, judgment and uncertainty. As such SWOT analysis is required for an efficient and simple analysis of the Penang National Park strategic ecotourism management and planning. SWOT analysis could be showed in various ways such as empirical observation, group interview or individual interview. For the project of Penang National Park, empirical observation was conducted on the natural phenomena, surrounding and conditions of facilities via SWOT analysis. Besides observation, SWOT analysis also obtained and searched information through secondary sources such as official documents, reports, journal publications and own 
opinion. Strengths, weaknesses, opportunities and threats (SWOT) analysis indicates a framework for helping the researchers or planners to identify and prioritize the main things, and to further identify the strategies of achieving them. SWOT analysis is a technique used to analyze the strengths, weaknesses, opportunities and threats of businesses (Ommani, 2011).

According to Pauline \& Sam (2003) SWOT ideally follow the step in a process which helps researcher to:

1. Appreciate the strengths of a situation, and you may then decide to build on these.

2. Define the weaknesses, which might researcher, choose to minimize.

3. Make the most of the opportunities that present themselves.

4. Recognize the possible threats and treat them in a planned and organized way.

\section{B.TOWS Analysis Technique}

TOWS strategies were developed as the next step of SWOT in developing alternative strategies (Weihrich, 1982). TOWS matrix strategies was developed based on combinations of factors relating to internal strengths and weakness with factors relating to the external opportunities and threat. TOWS matrix identifies four conceptual strategic groups based on SWOT: Strength and Opportunity (S-O Strategies), Strength and Threats (S-T Strategies), Weaknesses and Opportunities (W-O Strategies), and Weaknesses and Threats (W-T Strategies), for creating the alternative strategies for improvement.

The S-O strategies use strengths to maximize opportunities and $\mathrm{W}-\mathrm{O}$ strategies minimize the weaknesses by taking advantage of the opportunities. While S-T strategies utilize the strengths to minimize the effect of the threats and $\mathrm{W}-\mathrm{T}$ strategies are defensive strategies to minimize the weaknesses and threats. The advantage of TOWS analysis is the influence of prioritizes internal and external factors embedded in alternative strategies.

\section{C.Secondary Data}

Secondary data is the use of existing data to find answers for research questions that differ from the questions asked in the original research (Hinds et al., 1997). The purpose of using Secondary analysis is to discourse new research questions by analyzing previously collected data. Whereby, it is differs from approaches that seek to critically asses on theory, methods and findings from existing qualitative research and attempt to generate synthesis meaning from multiple studies. According to Hinds et al., (1997), our member have applied secondary analysis as data and to pursue interests distinct to those of original analysis and apply a new perspective or new conceptual focus to original research issues (Heaton, 1998) and describe the contemporary and historical attributes and behavior of individuals, societies, groups or organizations (Corti \& Thompson, 1995) or to provide case material for teaching and methodological development. (Corti \& Thompson, 1998).

According to Johnson et al (2009) stated Strategy is known as a direction and scope of an establishment over long term, which have achieves advantages in a changing environment through its configuration of resources and competences.

Figure 3.1: shows initial decision situation diagrams

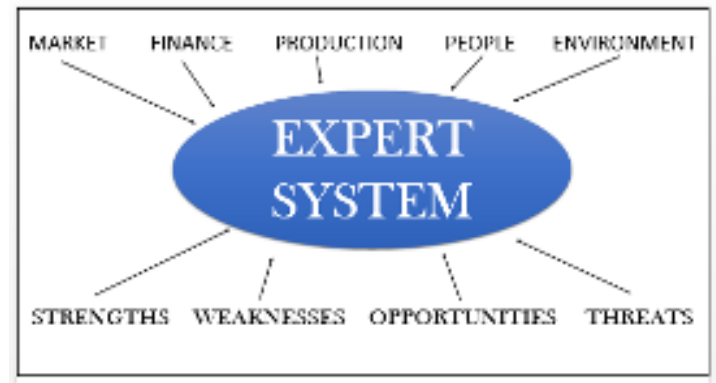

This method allows us to optimize the time used for research and standardize methodology and make it able to compare with different organizations. However, the disadvantage is that it does not measure subjectivity of given information and lost flexibility on unable to change procedure in some situation. Penang National park used SWOT analysis as a business analysis technique that perform which included products, services and markets to decide on the best strategy to achieve future growth.

\section{IV.RESULTS AND DISCUSSION}

Upon the analysis of the information and empirical observation that have gathered, we arranged it according to SWOT analysis in terms of the policy and organization in Penang National Park. Implementation of TOWS will be discussed at the Recommendation section

From the SWOT analysis, strengths indicator is important and brings beneficial quality to Penang National Park. Strength analysis is additional data that support on planning and incoming development. Penang National Park have provide good internal and external accessibility to tourist, internally like boats provided and also trekking path for adventurous tourist or excursionist. Tourist will also have no difficulty in getting to Penang National Park from the city by using public transportation such as public bus. Other than that, at the main entrance of Penang National Park, the visitors can also hire a nature guide for a walk in the park. Tour guide in Penang National Park are licensed tour guide in which they are bind under the Tourism Industry Act 1992. Under the section of Licensing of Tourist Guide, no person shall act, or hold himself out, as a tourist guide unless they are licensed (Tourism Industry Act 1992). 
Infrastructure such as campsite, toilet, hall and prayer room for Muslim have been built in Penang National Park. This has been highlighted by (Wern \& Weng, 2010), even if infrastructure development is necessary, green designs are recommended for sustainable development of the park. Other than that, turtle sanctuary located at Pantai keracut and Meromictic Lake gives Penang National Park its uniqueness and natural phenomenon. According to (Hong \& Chan, 2010) about 10 over 1266 hectares forest of Penang National Park consists of Meromictic Lake and lagoon.

Similar with Rantau Abang in Terengganu, turtle lovers would be able to see the green turtle (Chelonia Mydas) during the breeding season between April and August. Olive Ridley Turtle species will replace the green turtle until the next month of February the following year (Hong \& Chan, 2010). For Peninsular Malaysia, protected species are those listed under First and Second Schedule of the Wildlife Conservation Act 2010 (Act 716) and species listed under the Third Schedule of the International Trade in Endangered Species Act 2008 (Act 686) (Department of Wildlife And National Park Peninsular Malaysia, 2015). Furthermore, in strength indicator concern, signage of safety and rules have been setup by PNP for public guidance and rangers can be seen around, guarding in any emergency circumstances and to ensure tourist that come abide the rules and regulations. Rangers are very cooperative in explaining some regulations set up by Penang National Park. Its correlate with study by Sara (2015), an effective and enlightening approach explaining and interpreting the park to the visitors can contribute to sustaining waves of tourist educating them about what they are seeing and experiencing, assisting them in minimizing their potentially negative impacts, and encouraging those activities which ensure ongoing maintenance of the quality of environment

Famous with its beautiful coast, beaches and rich with its bird species, it allows Penang National Park for activities like camping, swimming boating and bird watching. Signage that reminds tourist to abide policy can be seen at Teluk Kampi and Pantai Kerachut. However, certain policy on conservation of ecotourism and natural heritage need to be highlighted to the tourist in signage form at place that can be seen.

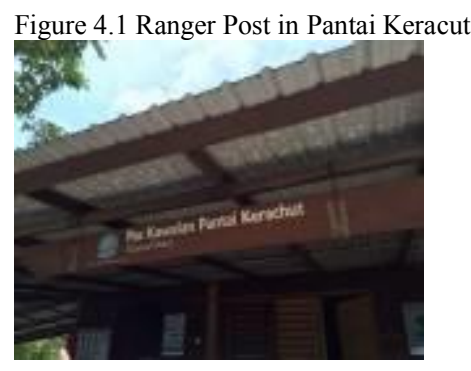

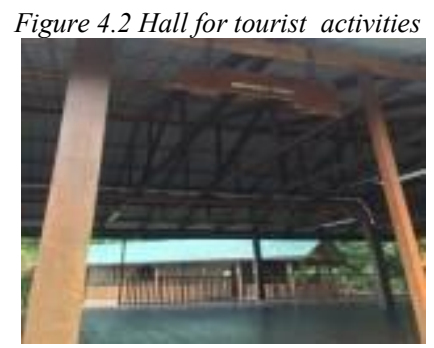

Figure 4.3: 'Do not Touch' signage

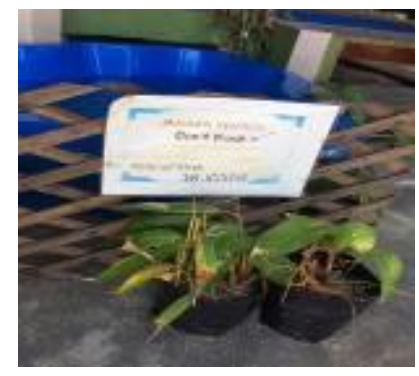

Figure 4.4 Red Flags for warning

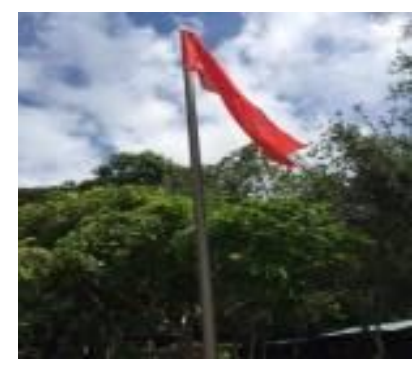

The weaknesses on Penang National Park policy can be observed during the fieldwork done such as no enforcement on littering policy. Litter can be found being abandoned anywhere at the park even though the amenities like dustbin is available. According to (Hong \& Chan, 2010), weakness indicates the presence of a negative state in an organization which could result in lesser efficiency of an activity being carried out. In this case, Taman Negara need to enforce the law because to preserve and conserve the biodiversity system. The Waters Act 1920 (Revised 1989), which provides for the control of rivers and streams certain States in Peninsular Malaysia, is another important legislation relating to natural resources. The importance of water is irrefutable especially when it comes to the issues of biodiversity conservation and management. This Act expressly prohibits pollution of rivers in these States by providing that no person is allowed, except under license, to discharge into any river the following matters:

(a) Any poisonous, noxious or polluting matter that will render such river as harmful to public health, animal, vegetation or its other beneficial users

(b) Any matter with temperature, chemical or biological content or effect in discoloring the water makes such river as 
potentially dangerous to public health, animal, vegetation or its other beneficial users

(c) Any matter, which due its physical nature or its effect in discoloring the water makes such water difficult to treat

(d) Oil of any nature irrespective of whether it is used, waste or otherwise.

There are two main federal legislations relating to land. Firstly, the National Land Code 1965, which generally provides for the registration of title to land and dealings of lands and the Land Conservation Act 1956 (revised 1991), which relates to the conservation of hill land and the protection from erosion of soil and inroad of silt.

Furthermore, improper signage on safety policy provided in Penang National Park can be seen as weaknesses. The proper signage of safety policy would help tourist and local knows and understand about the safety in Penang National Park. However, it's clearly seen that the signage not well maintained and faded and yellowish during fieldwork. It was supported by (Wern \& Weng, 2010), increment as human present as visitors to Penang National Park will exert pressure on the environment and through observation, solid wastes such as plastic and wrappers could be seen been dumped around the beautiful beaches especially around Pantai Keracut and Monkey Beach.

In this case if situation where a tourist or other visitor is injured on 'premises', the tourist is the plaintiff and the occupier of the premises, whoever or whatever that occupier may be, is the defendant. The legal cause of action underlying such 'occupier's liability' is the tort of negligence. To succeed in a negligence action, the plaintiff must prove all of the following which is that the defendant owes the plaintiff a duty of care (the duty of care), that the defendant has failed to conform to the required standard of care (the standard of care), that there has been material damage to the plaintiff (damage), caused by the defendant and which is not too remote. (Sadler, P., 2004) If Taman Negara was found guilty breach the duty which is provide the proper signage and put the warning risk properly, they might own owned the negligence and will be charged on it.

In addition to the weaknesses, Penang National Park did not charge any entrance fees to visitors. Insufficient funds from Government in maintain and preserving Penang National Park has led to some issues. It was suggested by (Wern \& Weng, 2010), to have a sustainable income, the Penang National Park must not solely depend on the funding from the government itself. In this case, Taman Negara Pulau Pinang should revise the price of permits and licenses that set by the Treasury. It is based on an Enactment of 1938/39. The price is proposed by the Department wildlife national park (DWNP) and must be supported by the Ministry of Tourism and the Cabinet before it goes to the Treasury (DWNP, 1987). The price should be charge for visitor not to make a profit but to collect a fund as a maintenance fees and conservation program to protect all the wildlife system.
Other weakness issue during the fieldwork done, it clearly can be seen that there are no person in charge on the sea entrance of Penang National Park near the loading boat area. It's supported by (Hong \& Chan, 2010) entrance of Penang National Park was found absence of zoning and security fence are weaknesses that can result trespassing of unregistered visitors through illegal entrance which could result in plant theft and illegal animal poaching. Under Marine Park Act 2004, enforcement and compounds can be issued by the Department of Marine Park Malaysia if such cases were found in Penang National Park.
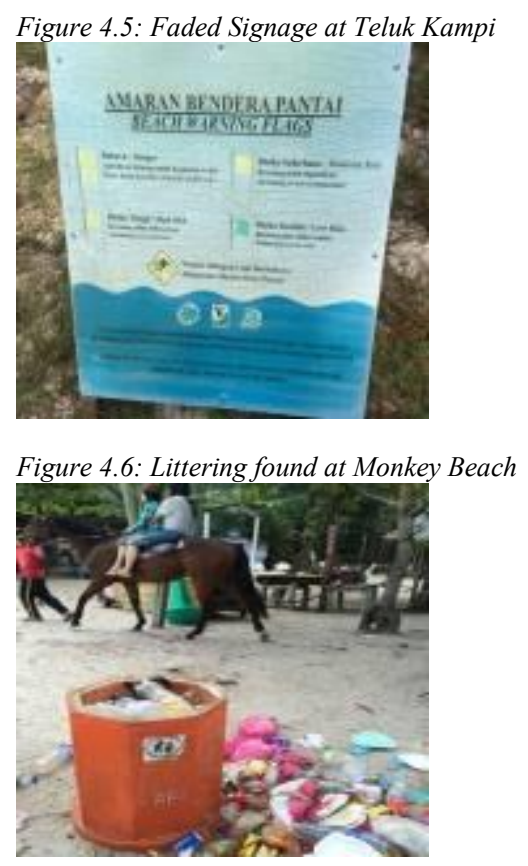

Figure 4.7: Information Centre located at Penang National Park is far from the coast area which results in lack of monitoring activities of trespassing

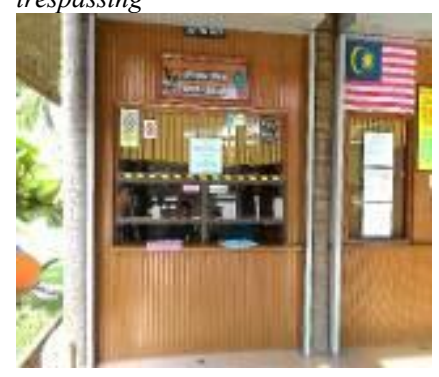

Figure 4.8: Fill and Register name before entering Penang National Park

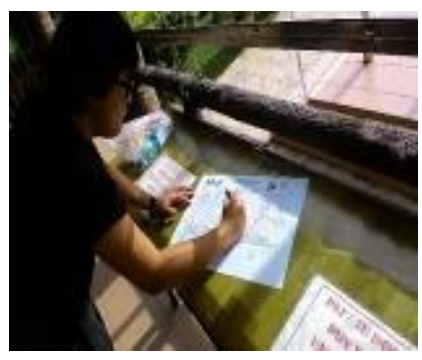


Although the weaknesses present, there are many opportunities indicator present in Penang National Park. Opportunities mean potentials that carry out for the certain place that can make it more success in future. In Penang National Park, it could be noticed that potential that carry out is The Centre for Marine and Coastal studies (CEMACS) as opportunity because the area is not polluted as a result of the development control area is higher than anywhere else ecotourism. CEMACS objective is to enhance the capability of conducting inter-integrated and multi-disciplinary studies leading towards solving problems related to marine and coastal ecosystems. According to (Wern \& Weng, 2010), APEX status required by USM, gives opportunity to promote and nurture Penang National Park as a world class National Park research forest.

In charging some entrance fees, revenue of Penang National Park can be increased. It was suggested by (Wern \& Weng, 2010), it was recommended that local could be charged at minimal fee while foreign visitors could be charge as higher fee as they could afford it and this fees could in turn be used for the maintenance of the facilities. The policy related to this, according to Act 224, National Park Act, 1980(Amendment 1983), under "Regulation" Item 11(1), "The Minister may, after consultation to the state Authority, make regulations not inconsistent with this Act as to set (i) the fees for the issues of permits to enter into a camp within National Park, for the admission of vehicles into and taking photographs within National Park or the services connected with the use of enjoyment in National Park"

Variety eco-tourism in Penang National Park is one of the opportunities that can boost this National Park that popular with unique features as compared to other National Park in Malaysia. This was strongly supported by (Wern \& Weng, 2010) stated that, pristine beaches, rich flora and fauna made Penang National Park vast potential to grow into world class center for eco-tourism attraction. It can be seen apart of that, creating environmental awareness through education is one of the potential to make Penang National Park as center of education. In the policy overview related to this, in ensuring that the virginity of this eco-tourism in National Park is never being abused, National Park Act, 1980(11) (1) stated that ;(d) the burning and cutting of vegetation within a national park; (e) the disposal of wildlife, vegetation of other things found in National Park" is prohibited and action can be taken to the culprits. In addition, Malaysia government is seriously promoting the important to biodiversity by launching National Policy of Biological Diversity (NPBD) in 1998.This would directive and act as a guide to all government agencies including State governments on the conservation and management of biological diversity in the country. It has outlines 15 strategies and 85 action plan.

Among the first measures taken by Malaysia was the conduct of a country survey on biological diversity cumulating in the "Assessment of Biological Diversity in Malaysia" in
1997, which was almost immediately followed by the launching of the National Policy on Biological Diversity. To provide legislative implementation of the broad objectives of the Policy, three specific legislations are to be put in place namely the Biosafety Act 2007 (Act 678), the Access to Genetic Resources Act and the National Biodiversity Council Act (both of which are still in the bill stage) (Isma, Norhayati, Azmi, \& Lokman, 2013).

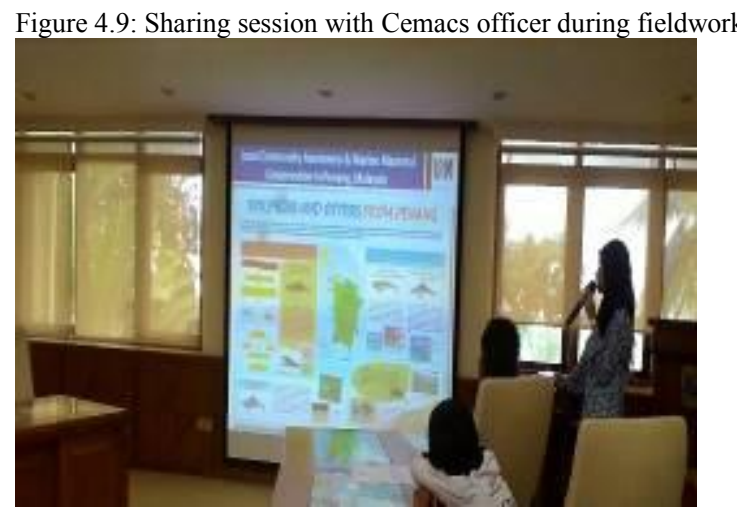

According to (Hong \& Chan, 2010), statement of intention or inflict damage on anything through unwanted action can caused threats happened. As threats indicator in this analysis, Penang National Park must control these human activities to make it balance to this ecosystem. The carrying capacity of beaches in Penang National Park must be controlled. When there are a lot of human activities as number of tourist is increased, the boats that comes to this place could affect the cleanliness of seawater. In relating to Act 127 Environmental Quality Act 1974, Part IV, Prohibition and Control of Pollution (25)(1) Restriction on pollution of inland waters, "No person shall, unless licensed, emit, discharge or deposit any environmentally hazardous substances, pollutants or wastes into any inland waters in contravention of the acceptable conditions under Section 21"

Monkey Beach is owned by the private company and is located in Penang National Park where the facilities and accessibility is low by using trekking and marine vehicles such as boats use. By this, visitors will not reach maximum capacity and can be optimized in a time. An individual ownership well causing no strict controls exist regarding the safety of visitors, such as horseback riding activities in coastal areas will pose a threat to other travelers. The growth of the competitiveness of the tourism products business resulted the area badly polluted caused by no basic amenities such as sufficient waste bins and public toilets.

The natural style of the steep coast sea causes it dangerous to visitor especially Teluk Kampi Beach and Kerachut Beach. The death has been recorded five cases in Teluk Kampi believed by drowned. Furthermore, other threats are like fishing boats have affected physical environment as it's constantly change resulted habitats in this area being disturbed. This place cause pollution from fishing boats and 
tourist boats which have less awareness of the natural habitat and beach erosion resulting in living creatures in that area will die or migrate to other areas. . In relating to policy, Fisheries Act 1980, Part VII (38)(1) Turtle and Inland Fisheries, The Federal Authority make rules for (c ) to provide licensing of fishing vessels and fishing appliances operating or use in riverine waters.

Loss of flora and fauna can be seen as other threats to the policy at Penang National Park. Visitors also have unconsciously learned to steal flowers or ornamental plants of the National Park (Wern \& Weng, 2010). In addition, eggs are also reportedly stolen from the coastal areas that will reduce the chance of turtles visit in the future (Hong \& Chan, 2010). Moreover, to steal and deprive plants, an invasion farmer in the vicinity of Penang National Park has led to the destruction of trees as a result of deforestation. This situation can be seen as serious and action must be taken by authorities to overcome this issue. Policy related to this is Wildlife Conservation Act,2010, Part IV(74) Damaging nest or eggs of protected wildlife "Any person who damage or destroys the nest or eggs of a protected wildlife commits and offence and shall, on conviction be liable to a fine not exceeding twenty thousand ringgit or to imprisonment for a term not exceeding one year or both"and item (75) Damaging,etc., nest or eggs of totally protected wildlife," Any person who damage or destroys the nest or eggs of a protected wildlife commits and offence and shall, on conviction be liable to a fine not exceeding fifty thousand ringgit or to imprisonment for a term not exceeding two years or both"

Hong \& Chan (2012) also noted that some places have also been illegally planted with fruit trees, herbs and flowers. It may interfere with or affect the forest ecosystem as a part of the area to be cleared for agriculture. This situation is worrying as officer in Penang National Park agrees that local people staying around illegally requesting some land for their vegetation. Policy related stated in Act 224, National Park Act, 1980(Amendment 1983), under 9(1) (4),"Save by virtue of any right conferred by or acquired under in respect of any lease or permit under subsection (1) or otherwise in this Act Provided, no person other than officer may reside on, enter, use or occupy any land within and forming part of National Park without the permission of the Director General"

According to Isma (2013) "Wildlife Act 1972, Unlicensed persons are prohibited from the following activities: (a) Shooting, killing or taking any protected wild animal or wild bird or the nest or egg; (b) Carrying on the business of a dealer of wild animal or wild bird; (c) Carrying on the business of a taxidermist; (d) Housing, confining or breeding a protected wild animal or wild bird other than as a dealer or a taxidermist; (e) Importing or exporting from Peninsular Malaysia any protected wild animal or wild bird or part thereof; (f) Keeping a trophy of any protected wild animal or wild bird (in any form of skins or feathers of wild animal or wild bird, stuffed or mounted wild animal or wild bird or any horn, tusk, tooth, nail or scale); and (g) Entering a wild life sanctuary or a wild life reserve. Under this Act, a State Ruler or Yang di Pertua Negeri is allowed to declare any state land to be a wild life reserve or a wild life sanctuary. Entry to these wild life reserves or wild life sanctuaries is prohibited unless a written permit is first obtained from the Director for Wild Life and national Parks. Even then, the law is very clear that those capable to apply for the permit must either be a licensed hunter or someone who satisfies the Director in writing that his entry into the wild life reserve or wild life sanctuary is for any of the purposes of art, science and recreation.

Even though threats bring negative impact to Penang National Park, however Sara (2015) stated that visitors with higher education have more positive attitudes about value Penang National Park and are more concerned about seeing the improvements in management and tourism facilities in Penang National Park. By improving some policies and organization such as putting informative signboards in Penang National Park, it can helps management of PNP in manage the national park smoothly, effectively and educate visitors when visiting National Park. This supported by Sara (2015), providing information directly to the visitors may be their only opportunity to learn about the ecological importance of these protective areas in harmoniously balancing between plant and animal species in nature.
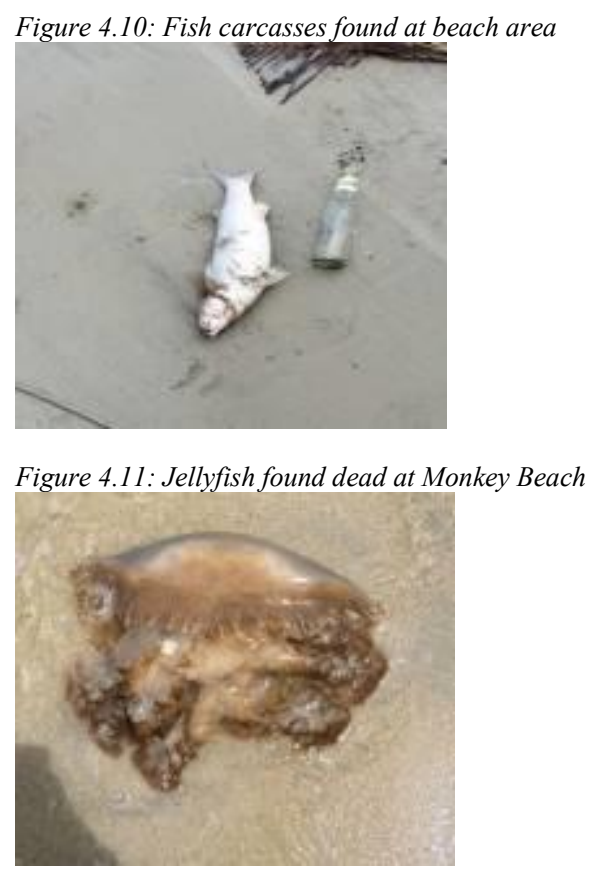
Figure 4.12: Human activities cause seawater polluted

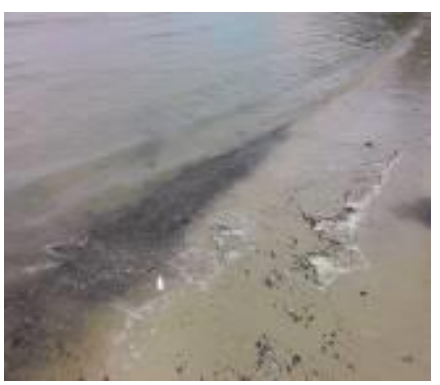

Figure 4.13 Improper Tourism business in Monkey Beach effects safety

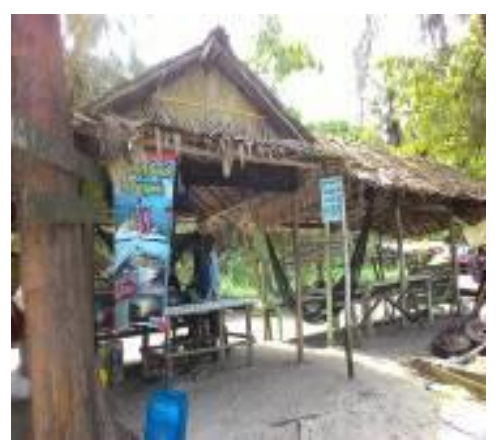

Figure 4.1 Improper facilities bring safety issues

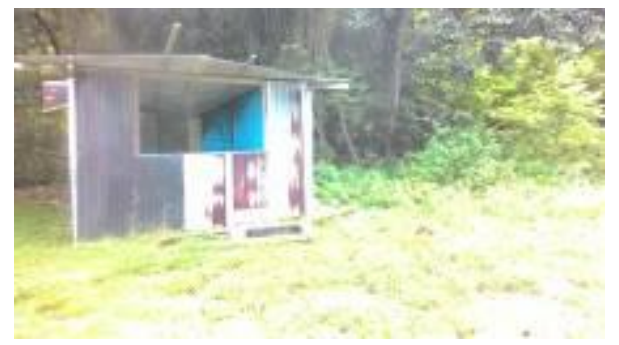

TABLE 4.1 SWOT AND TOWS ANALYSIS OF PENANG NATIONAL PARK

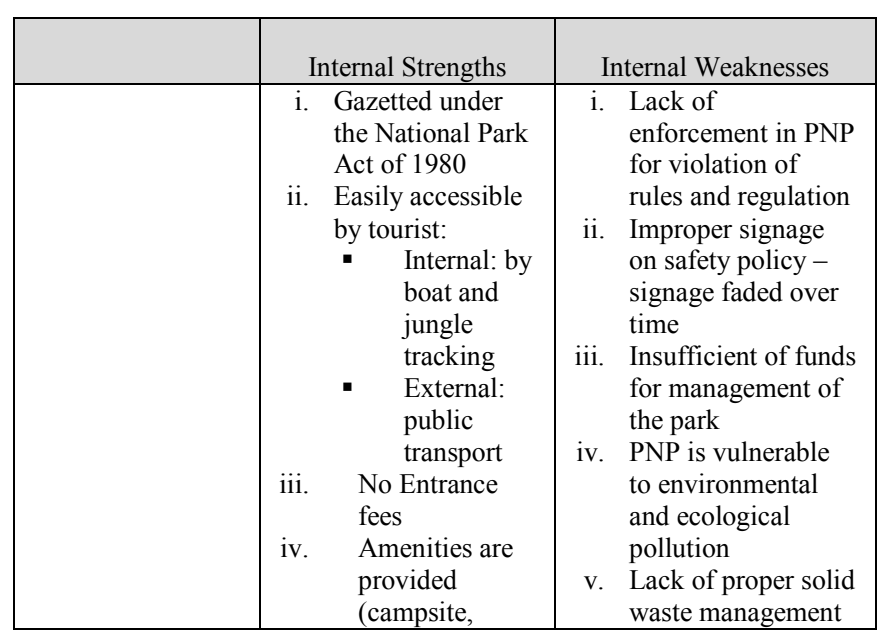

\begin{tabular}{|c|c|c|}
\hline & \begin{tabular}{|rl} 
& toilets, hall, \\
& Prayer room for \\
& Muslim, table) \\
v. & Turtle \\
vi. & sanctuary \\
& Unique \\
& landscape- \\
& Lake \\
& Meromictic \\
vii. & Historical \\
& lighthouse and \\
& Acehnese tomb \\
viii. & Safety and \\
& rules: \\
& - Equip with \\
& signage and \\
& warning \\
& Rangers for \\
& standby \\
& Equipped \\
- & with \\
& Tsunami \\
& alarm \\
System
\end{tabular} & 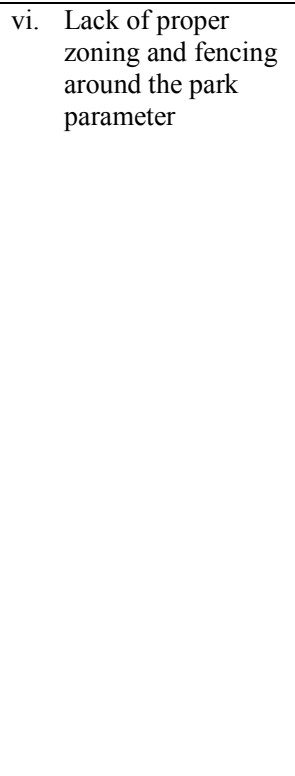 \\
\hline $\begin{array}{c}\text { External } \\
\text { Opportunities }\end{array}$ & $\begin{array}{c}\text { Strength - } \\
\text { Opportunities } \\
\text { Strategies } \\
(\mathrm{S}-\mathrm{O})\end{array}$ & $\begin{array}{c}\text { Weakness - } \\
\text { Opportunities Strategies } \\
(\mathrm{W}-\mathrm{O})\end{array}$ \\
\hline $\begin{aligned} & \text { i. } \begin{array}{l}\text { Creating } \\
\text { environmenta } \\
\text { l awareness } \\
\text { through } \\
\text { education } \\
\text { program }\end{array} \\
& \text { ii. } \begin{array}{l}\text { Generate } \\
\text { additional }\end{array} \\
& \text { income } \\
& \text { through } \\
& \text { collecting } \\
& \text { entrance fees } \\
& \text { to PNP } \\
& \text { iii. } \\
& \text { Cemacs as } \\
& \text { opportunities } \\
& \text { iv. } \\
& \text { Variety } \\
& \text { ecotourism } \\
& \text { v. } \text { Generate } \\
& \text { sustainable } \\
& \text { income } \\
& \text { through } \\
& \text { ecotourism } \\
& \text { partnership }\end{aligned}$ & $\begin{aligned} & \text { i. } \text { Collaborate with } \\
& \text { service providers } \\
& \text { in tourism to } \\
& \text { promoting eco- } \\
& \text { tourism activities } \\
& \text { and tour } \\
& \text { packages. } \\
& \text { ii. } \begin{array}{l}\text { Develop entrance } \\
\text { fee plan }\end{array} \\
& \text { iii. Partnership with } \\
& \text { NGO's to be the } \\
& \text { official hub for } \\
& \text { environmental } \\
& \text { education } \\
& \text { iv. Improve } \\
& \text { partnership with } \\
& \text { Cemacs to attract } \\
& \text { international } \\
& \text { researcher in } \\
& \text { creating data and } \\
& \text { define the } \\
& \text { valuable flora and } \\
& \text { fauna of the park }\end{aligned}$ & $\begin{array}{ll}\text { i. } & \begin{array}{l}\text { Enhance the } \\
\text { enforcement of PNP } \\
\text { by engaging more }\end{array} \\
\text { rangers / volunteers } \\
\text { ii. } & \begin{array}{l}\text { Create signboard to } \\
\text { educate the visitors } \\
\text { the importance to } \\
\text { maintain the }\end{array} \\
\text { cleanliness of the } \\
\text { park } \\
\text { iii. } \\
\text { Planning for a } \\
\text { better solid waste } \\
\text { management and } \\
\text { collection } \\
\text { iv. Integrate the solid } \\
\text { waste management } \\
\text { plan into } \\
\text { environmental } \\
\text { education }\end{array}$ \\
\hline External Threats & $\begin{array}{c}\text { Strength - Threat } \\
\text { Strategies } \\
(\mathrm{S}-\mathrm{T}) \\
\end{array}$ & $\begin{array}{c}\text { Weakness - Threat } \\
\text { Strategies } \\
(\mathrm{W}-\mathrm{T}) \\
\end{array}$ \\
\hline $\begin{aligned} & \text { i. } \begin{array}{l}\text { Loss of flora } \\
\text { and fauna }\end{array} \\
& \text { ii. } \text { The } \\
& \text { cleanliness of } \\
& \text { the sea will } \\
& \text { be affected } \\
& \text { by } \\
& \text { uncontrolled } \\
& \text { human } \\
& \text { activities } \\
& \text { iii. Threat of } \\
& \text { fishing boats } \\
& \text { iv. Threats of } \\
& \text { steep coast }\end{aligned}$ & $\begin{aligned} & \text { i. } \begin{array}{l}\text { Stricter fines for } \\
\text { poachers and } \\
\text { plant theft }\end{array} \\
& \text { ii. } \text { Barriers to enter } \\
& \text { to Taman Negara } \\
& \text { Pulau Pinang } \\
& \text { (limit the carrying } \\
& \text { capacity) } \\
& \text { iii. Form partnership } \\
& \text { with Cemecs to } \\
& \text { manage part of } \\
& \text { the park } \\
& \text { iv. Conflicts between } \\
& \text { stakeholders need }\end{aligned}$ & $\begin{aligned} & \text { i. } \begin{array}{l}\text { Develop clear } \\
\text { border around the } \\
\text { parameters of }\end{array} \\
& \text { Penang National } \\
& \text { Park } \\
& \text { ii. } \\
& \text { Benchmark and } \\
& \text { monitor the } \\
& \text { progress of S-T i, } \\
& \text { iii, v }\end{aligned}$ \\
\hline
\end{tabular}




\begin{tabular}{|c|c|c|}
\hline & $\begin{array}{l}\text { sea } \\
\text { Farmers } \\
\text { encroachmen } \\
t\end{array}$ & $\begin{array}{ll}\text { to be resolved } \\
\text { v. Strict } \\
\text { enforcement of } \\
\text { gazettement and } \\
\text { strong political } \\
\text { will }\end{array}$ \\
\hline
\end{tabular}

\section{V.RECOMMENDATION}

Being one of the smallest national park in the world, Penang National Park (PNP) as a well-known world-class ecotourism destination has been discussed by researches over the past few years (Hong \& Chan, 2010). The unique land area that comprises of forest, hill, lake and costal area are the habitat for few hundred species of flora and fauna. Therefore, it is recommended that sustainable development approach should be taken while conserving the sensitive area inside the national park. Though, every year government allocated fund in the park maintenance, it still have much potential to be improved. For example, in order to enhance the protection and preserve the coastal area, it could open for adoption by private sector as what have been done by Wildlife Reserves Singapore (WRS) (Sponsorship and Adoption, 2014). WRS encourages private sectors to adopt the animals in zoo as mainly through financial support that could be implemented to PNP as long as they are adhering to the National Ecotourism Plan Guidelines No. 4 and 9 about conserving national parks and coastal area. In addition to that, this could be the private company Corporate Social Responsibility (CSR) program that helps to benefit the society and create positive images and so create a mutual relationship within the public and private sector.

Malaysia's tourism vision involves making this industry a primary source of natural revenue and a major contributor to the socio-economic development of the nation. Tourism sector has great potential on contributing numerous financial benefits, directly or indirectly which also included generate growth and development for a nation, job opportunities, foreign exchange earnings and government revenue. In addition, Penang National Park has it potential to serve as a major tourist destination for ecotourism activities not only in Penang State but also for the northern Peninsular Malaysia. As part of the strategies to enhance this strength, PNP could bundle up with Penang Butterfly Farm that is located in the same area of Teluk Bahang and sell together as a package. It would able to help tourists reduce their travelling cost and attract them to visit and experience the different side of Penang. Other than that, it could incorporate with Balik Pulau agro tourism products with the objective to boost and promote Teluk Bahang as the ecotourism hub in northern region of Malaysia.

Besides, partnership with NGOs like Malaysia Nature Society (MNS) and WWF (World Wide Fund) Malaysia and collaborate with their conservation and education projects that will help in preserving the national park and attracts nature lovers to participants in their voluntary works. Other than that, collaborating with CEMACS could be one of the way to attract international researchers in recording valuable data about the flora and fauna of the park. Hence, collaboration approach able to strengthen the networking between PNP and NGOs, while they could increase the awareness within the public too.

While promoting the park as a popular tourist destination, the conservation and preservation of PNP to provide great experiences to visitors should not be neglected, as visitors' satisfaction is one of the most important elements to maintain a destination. As discussed previously in SWOT analysis, solid waste management is one of the aspects that the park should improve on. It is known that some part of the park is private own land and so it is not under the park authority competence to ensure the cleanliness of that area. For instance, according to National Forestry Act 1984 (Act 313) Part VII No. 83, no one shall commit offensive littering in a permanent reserved forest. It is recommended that the authority should enforce this act strictly and compound to those who breaks the law. Other than that, increase awareness and educate the visitors are one of the vital steps to encounter the issue. Warning signboard or verbal advice could be done when the visitors registered at the entrance and be reminded by the rangers that station in the park. Visitors should be educated to understand the importance of protecting the environment and the negative impacts that their action brings to the flora and fauna.

Although at the moment, PNP have not reach it maximum carrying capacity, however planning and implementation in controlling the number of park visitors should be anticipated in the early stage, as increase in number of visitor often equal to increase in physical infrastructure to meet demands for public services, which indirectly increase in disruption of habitat of the flora and fauna in the park (Narayan, 2008). National Park Service Organic Act 1916 is used to preserve the national park lands. This act indirectly can control the carrying capacity of visitors to Penang National Park. Charging visitor fees not only able to reduce the number of visitor per day, other than solely depend on government funding, it will also contribute to the income of the park,. It is recommended that the locals to be charged at minimal fee while foreign visitors to be charged at a higher fee as they could afford more. Fee can also be charged for activities such as camping and grouping activities as well. The collection could be used for maintenance of the park. As to proper manage and monitor the activities in the park, the collection should use to increase the employment rate to cater for a better monitor and management of the park.

There are few departments involve in managing PNP, among them as the main organization are Department of Wildlife and National Parks together with the State Councils, Forest Department and Tourism Ministry. Conflict arises when their objectives are different in managing the national park and the demarcation of responsibilities is not cleared in term of 
conservation and development within the reserved park (Ibrahim \& Hassan, 2011). Therefore, the committee in the National Park Advisory Council which form under Section 5 of the 1980 National Parks Act should work together and realign their duties to minimize the gap and so to maintain sustainable development.

As of all the issues and problems PNP faced such as poachers and plant theft, farmers encroachment due to unclear boundary and solid waste disposal issue, strong support from the enforcement authorities is needed before the conservation and developments strategies and approaches could be carried out. Therefore, strict enforcement according to the laws and guidelines is the utmost important task to carry on continuously and aid in benchmarking and monitoring the conservation progress.

Sustainable approaches should be implemented at all time to protect the park from the impacts of encroachment and intrusion that are increasing alongside with the modern development in the island.

\section{CONCLUSION}

Penang National Park has potential to serve as a major tourist destination for ecotourism activities not just in Penang State but also peninsular Malaysia. With the right policy and regulation of management could develop it to become a wellknown ecotourism destination. However, a balance needs to be struck between ecotourism development and environmental conservation to ensure the sustainability. In the minor and major aspects by identified the SWOT analysis shows that it is possible to overcome each weakness and threat by strategizing the policy and regulation management plan to turn the national park into a better sustainable ecotourism destination. Besides that, awareness and environmental education also play crucial key to sustain the environment ecosystem. This paper has identified the threats on the national park. What remains is a daunting task but achievable challenge to reduce these threats via strict enforcement, and involvement of all stakeholder and local communities in order to work together for the benefits of the park.

\section{ACKNOWLEDGEMENT}

We would like to express our special gratitude and thanks to the Prof. Madya. Dr. Aziz and Dr. Zul Zaki for giving us such attention and time in developing the project and helped us out with their abilities.

We are highly indebted to all staff at Taman Negara Pulau Pinang and USM Research Centre from the top to bottom management for their guidance and constant supervision as well as for providing necessary information regarding the project and also for their support in completing the project. Thanks to all team members for their kind co-operation and encouragement that helped to complete this project.

\section{REFERENCES}

[1] Abdul Wahab, H., \& Yaacob, N. (2012). Pencemaran sungai: Analsis peruntukan undang-undang di bawah Akta Kualiti Alam Sekeliling 1974.Kanun (Jurnal Undang-undang Malaysia), 24(1), 77-93.

Azmi, W.N.W.M., Akil, M.R., \& Mansor, H. (2008). Kesan perubahan penduduk terhadap alam sekitar. In Rujukan Kompak Geografi PMR (1ST ed., pp. 106-110). Shah alam, Selangor: Arah Pendidikan.

[3] Bransbury, J. (1993). A birdwatcher's guide to Malaysia. Waymark.

[4] Cannon, C. H., \& Leighton, M. (2004). Tree species distributions across five habitats in a Bornean rain forest. Journal of Vegetation Science, 15(2), 257-266.

Chan, N.W. (2003) Striking A Balance between Ecotourism and Environmental Protection. In N.W.Chan (Editor) Introductory Course on Ecotourism Penang: British Council DFID Higher Education Links and School of Humanities. Universiti Sains Malaysia,pp: 21-33.

Chan, N.W (2009) Issues and challenges of managing natural heritage in Penang National Park, Malaysia. In Proceedings of the 2nd National Symposium on Tourism Research-Theories \& applications, Penang, Malaysia 18 July 2009; pp. 111-123.

Corti L and Thompson P (1995) Archiving qualitative research data. Social Research Update (10), Department of Sociology, University of Surrey. Online journal available at: http:// www.soc.surrey.ac.uk/sru/SRU2SRU102.html (accessed 15 September 2004).

[8] Corti L and Thompson P (1998) Are you sitting on your qualitative data? Qualidata's mission. International Journal of Social Research Methodology 1(1): 85-89.

[9] Gillis, M. (1988). Malaysia: public policies and the tropical forest. Public policies and the misuse of forest resources, 115-64.

[10] Heaton J (2004) Reworking Qualitative Data. London: Sage Publications.Hinds PS, Vogel RJ and Clarke-Steffen L (1997) The possibilities and pitfalls of doing a secondary analysis of a qualitative dataset. Qualitative Health Research 7(3): 408-424.

[11] Hearne, R.R. \& Salinas, Z.M (2002) The use of choice experiments in the analysis of tourist preferences for ecotourism development in Costa Rica. J. Environ. Manag. 2002, 65, 153-163.

[12] Herningtyas, R., Wirasenjaya, A. M., Anam, M. Z., Nugroho, B. W., HariatiHussin, M., Jauhola, M., \& Muslikhati, S. (2012). Halaman 1 "The "English School", Southeast Asia, and Indonesia: Locating and Defending Productive "middle ground Linda Quayle; $\mathrm{PhD}$ graduand, School of Social and Political Sciences, The University of Melbourne, Australia. Halaman 22 Weak State Sebagai Sebuah Ancaman Keamanan: Studi Kasus Kolombia.Jurnal Hubungan Internasional| Vol, 5(1).

[13] Hinds, P, S, Vogel, R, J. and Clarke-Steffen L.(1997) The possibilities and pitfalls of doing a secondary analysis of a qualitative dataset. Qualitative Health Research 7(3): 408-424.

[14] Hong, C.-W., \& Chan, N.-W. (2010). Srength-weaknessopportunities-threats Analysis of Penang National Park for Strategic Ecotourism Management. World Applied Science Journal, 136-145. 
Hutchings, P., \& Saenger, P. (1987). Ecology of mangroves. Quensland UniversityPress. Ibrahim, Y., \& Hassan, M. S. (2011). Tourism management at Taman Negara (National Park), Pahang, Malaysia: Conflict and synergy. Journal of Ritsumeikan Social Sciences and Humanities, 3, 109-122. National Forestry Act of 1984

[16] Isma, W. T., Norhayati, M. T., Azmi, M. R., \& Lokman, H. M. (2013). The Laws on Policies for the Sustainable Management of Biodiversity in Malaysia. Journal of Sustainability and Science Management, 276-289.

[17] Jackson, S. E., Joshi, A., \& Erhardt, N. L. (2003). Recent research on team and organizational diversity: SWOT analysis and implications. Journal of management, 29(6), 801-830.

[18] J.C.B. Bontje, Ondernemersboek: Doe-het-zelf methode voor Doorlichten en plannen maken in kleine en middelgrote ondernemingen, CED Samson, Brussel, 1988.

[19] Johnson, G., Whittington, R. and Scholes, K. (2009), Exploring Corporate Strategy with MyStrategyLab, Financial Times/Prentice Hall.

[20] Jusoff, K., \& Taha, D. (2009). Managing Sustainable Mangrove Forests in Peninsular Malaysia. JSD Journal of Sustainable Development

[21] Kaffashi, S., Radam, A., Shamsudin M, N., Yacob, M, R. \& Nordin, N, H (2015) Ecological Conservation, Ecotourism, and Sustainable Management: The Case of Penang National Park. Forests 6(7):2345-2370.

[22] Narayan, S (2008). Below the Surface: The Impacts of Ecotourism in Costa Rica. University of Michigan

[23] Ommani, A,R. (2011) Strengths, weaknesses, opportunities and threats (SWOT) analysis for farming system businesses management: Case of wheat farmers of Shadervan District, Shoushtar Township, Iran. African Journal of Business Management Vol. 5(22), pp. 9448-9454.

Pickton, D. W., \& Wright, S. (1998). What's swot in strategic analysis?.Strategic change, 7(2), 101-109.

Samdin, Z. \& Aziz, Y.A (2011) The Role of Socio-demographic and Economics on Ecotourism Activities at the Penang National Park, Malaysia: A Services Marketing Perspective. In Proceedings of The 2nd International Research Symposium in Service Management Yogyakarta, Indonesia, 26-30 July 2011.

[26] Sara, K., Alias, R., Shamsudin, M. N., Rusli, Y. M., \& Hanim, N. N. (2015). Ecological Conservation,Ecotourism and sustainable management: The case of Penang National Park. Forests 2015, 2345-2370.
[27] Vincent, J. R., Wan, L. F., Chang, Y. T., Noriha, M., \& Davison, G. W. (1993).Malaysian National Conservation Strategy. Volume 4: Natural Resource Accounting. Economic Planning Unit, Prime Minister's Department, Kuala Lumpur.

[28] Weihrich, H. (1982) The TOWS matrix- A tool for situational analysis, Long Range Planning, Vol. 15, No. 2, 54 - 66.

[29] Wern, H. C., \& Weng, C. N. (2010). The Potential, Threat and Challenges in Sustainable Development in Penang National Park. Malaysian Journal of Environmental Management, 95-109.

[30] Department of Wildlife and National Park Peninsular Malaysia (2015) Date of Coming into Operation of the Wildlife Conservation Act 2010. Retrieved on Dec 1, 2015, from http://www.wildlife.gov.my

[31] Kementerian Kebudayaan, Kesenian dan Pelancongan (1997) Pelan Ekopelancongan Kebangsaan Malaysia, Garis Panduan No. 9. Retrieved December 2, 2015, from www.motour.gov.my/en/download/finish/35-garis-panduan-ekopelancongan/195-garis-panduan-kawasan-pantai

[32] Malaysia (2006) National Parks Act 1980 incorporating all amendments up to 1 January 2006, The Commissioner of Law Revision, Malaysia. Retrieved December 2, 2015, from http://www.agc.gov.my/Akta/Vol.5/Akta226-Akta Taman Negara.pdf

[33] Meromictic Lake Pantai Kerachut (n.d.). Retrieved December 13, 2015.Penang National Park (n.d.). Retrieved November 28, 2015, from https://en.wikipedia.org/wiki/Penang_National_Park. Retrieved 28 November 2015

[34] Taman Negara Pulau Pinang. (n.d.). Retrieved December 18, 2015. Undang-undang Malaysia, (2012). Akta Perikanan 1985.

[35] Pelan Ekopelancongan Kebangsaan Malaysia, Garis Panduan No 4 Taman Negara, Hutan Simpan dan Hutan Lain

[36] Pelan Ekopelancongan Kebangsaan Malaysia, Garis Panduan No. 9 Kawasan Pantai

(http://www.justice.gov/enrd/nps-organic-act)

[37] Penang National Park (n.d.). Retrieved December 2, 2015, from http://www.tourism.gov.my/en/us/places/states-ofmalaysia/penang/penang-national-park

[38] Sponsorship and Adoption. (2014). Retrieved November 28, 2015, fromhttp://www.wrs.com.sg/getinvolved-sponsorshipadoption.html

[39] Visiting the National Park in Penang Malaysia (n.d.). Retrieved November 28, 2015, from http://www.travel-penangmalaysia.com/penang-national-park.html. 